UDC 378.011.3-057.175:338.46]:004

DOI https://doi.org/10.31470/2415-3729-2021-13-218-231

Theoretical Aspects of the Formation of Digital Competence of Future Vocational Training (Service Sector) Pedagogues in the Process of Professional Training

\title{
Nataliia Redziuk
}

First-year graduate student, 015 «Vocational education»,

Pereiaslav-Khmelnytskyi Hryhorii Skovoroda State Pedagogical University $\triangle$ 30, Sukhomlynskyi Str., Pereiaslav, Kyiv Region, Ukraine, 08401

E-mail: natatkachuk473@gmail.com

ORCID: http://orcid.org/0000-0002-8697-349X

\section{Viacheslav Riznyk}

Doctor of Philosophy in Pedagogy (Ph.D), Associate Professor of the Department of Vocational Education,

Pereiaslav-Khmelnytskyi Hryhorii Skovoroda State Pedagogical University $\triangle$ 30, Sukhomlynskyi Str., Pereiaslav, Kyiv Region, Ukraine, 08401

E-mail: riznyk84@gmail.com

ORCID: http://orcid.org/0000-0002-6083-2242

Date of receipt of the article: April 11, 2021 Article accepted for publication: June 02, 2021

Теоретичні аспекти формування цифрової компетентності майбутніх педагогів професійного навчання (сфера обслуговування) у процесі професійної підготовки

\section{Наталія Павлівна Редзюк}

Аспірантка I курсу н.п. 015 «Професійна освіта»

ДВНЗ «Переяслав-Хмельницький державний педагогічний

університет імені Григорія Сковороди»

$\triangle$ вул. Сухомлинського, 30, м. Переяслав, Київська обл., Україна, 08401 


\section{Вячеслав Володимирович Різник}

кандитат педагогічних наук, доцент кафедри професійної освіти ДВНЗ «Переяслав-Хмельницький державний педагогічний університет імені Григорія Сковороди»

$\triangle$ вул. Сухомлинського, 30, м. Переяслав, Київська обл., Україна, 08401

Дата надходження статті: 11 квітня 2021 р. Стаття прийнята до друку: 02 червня 2021 р.

\section{Abstract}

The article analyzes the European standards for the evaluating digital competence, which are an important tool for increasing the level of digital competence of specialists in the field of education. The purpose of the article is to substantiate the essence and importance of forming the digital competence of future vocational training (service sphere) teachers in the process of professional training. Methods. The authors use general scientific research methods as analysis, synthesis, generalization and systematization of scientific literature. The results. To define the concept of digital competence, the various approaches and terminology used in modern scientific and pedagogical literature have been studied. The semantic content of the concept of digital competence is a leading sign of digital literacy, and characterizes the skills of working in the information and communication environment, and its sociocultural component (relevant values and personal experience). The effectiveness of information and communication technologies (ICT) is positively influenced by the informatization of the education system, which contributes to the formation of professional competencies of future teachers. One of the defining components of professional competence is the vocational training (service sector) teacher's digital competence, interpreted as one of the key qualities and skills for effective, informative and systematic use of ICT in their activities, indicating the teacher's mobility, modernity and competitiveness. Currently, there is a growing demand for education professionals with non-standard thinking and the ability to promote modern content in education. Conclusions. The main attention in the article is focused on the prospects of development of this competence in future specialists in the specialty "Vocational education (Service secrtor)». The authors highlight the structure of the formation 
of digital competence of future vocational training (service sector) teachers in the process of professional training, namely: digitalization of the educational process, improving efficiency and transformation of interpersonal communication.

Key words: digitalization, informatization, digital competence, vocational training (service sphere), information and communication technologies (ICT), educational process.

\section{References}

1. «Shcho take SmartEducation?»(2017). Rozumna osvita dlia rozumnoho suspilstva. [Smart education for a smart society]. Retrieved fromhttp://smarteducatoin.blogspot.com/2017/06/smart-education. html? $\mathrm{m}=1$ [in Ukrainian].

2. Bykov V. Yu. (2016). «Navchalne seredovyshche suchasnykh pedahohichnykh system» [Learning environment of modern pedagogical systems]. Osvita Zaporizkoho kraiu -Education of the Zaporizhzhia region. Retrieved from http://virtkafedra.ucoz.ua/el_gurnal /pages/ vyp1/Bykov.pdf [in Ukrainian].

3. Christine Redecker, Yves Punie (2017). European Framework for the Digital Competence of Educators DigCompEdu. Publications Office of the European Union. Luxembourg, 93.

4. Genseryk G. (2019). Digital economy and digital society. Series of monographs Faculty of Architecture, Civil Engineering and Applied Arts Katowice School of Technology. Wydawnictwo Wyższej Szkoty Technicznej w Katowicach, 130-135 [in English].

5. Haluziak V.M. (2016). Struktura zahalnopedahohichnoi kompetentnosti vchytelia [The structure of general pedagogical competence of a teacher]. Vinnytsia : TOV «Nilan-LTD» [in Ukrainian].

6. Henseruk H.R. (2019). Tsyfrova kompetentnist yak odna iz profesiino znachushchykh kompetentnostei maibutnikh uchyteliv [Digital competence as one of the professionally significant competencies of future teachers]. Open educational e-environment of modern University, №6 [in Ukrainian].

7. Henseruk H.R., Martyniuk S.V. (2019) Rozvytok tsyfrovoi kompetentnosti maibutnikh uchyteliv v umovakh tsyfrovoho osvitnoho seredovyshcha Zakladu Vyshchoi Osvity [Development of digital competence of future teachers in the digital educational environment 
of the Institution of Higher Education]. Innovatsiina pedahohika. Vydavnychyi dim "Helvetyka» - Innovative pedagogy. Helvetica Publishing House, 19 (2), 158-162 [in Ukrainian].

8. Kandahura K. (2018). Osvita v umovakh kroskulturnoho seredovyshcha [Education in a cross-cultural environment]. Smartosvita: resursy ta perspektyvy: materialy III Mizhnar. nauk.-metod. konf. (Kyiv, 7 hrudnia 2018 r.) : tezy dopovidei. Kyiv. nats. torh.-ekon. un-tSmart-education: resources and prospects: materials III International. scientific method conf. (Kyiv, December 7, 2018): abstracts of reports. Kyiv national trade and economy university. [in Ukrainian].

9. Kontseptsiia novoi ukrainskoi shkoly (2016). [The Concept of the New Ukrainian School]. Retrieved from https://mon.gov.ua/storage/ app/media/zagalna\%20serednya/nova-ukrainska-shkola-compressed. pdf [in Ukrainian].

10. Kontseptsiia rozvytku tsyfrovoi ekonomiky ta suspilstva Ukrainy na 2018 - 2020 roky [The concept of development of the digital economy and society of Ukraine for 2018-2020]. Retrieved from https:// zakon.rada.gov.ua/laws/show/67-2018-\%D1\%80 [in Ukrainian].

11. Longman Dictionary of Contemporary English (2007). Pearson Education Limited. - Edinburg Gate, Harlow, Essex, England, 4th edition, 1834 [in English].

12. Morze, N., Bazeliuk, O., Vorotnikova, I., Dementiievska, N., Zakhar, O., Nanaieva, T., Pasichnyk, O., \& Chernikova, L. (2019). OPYS TSYFROVOI KOMPETENTNOSTI PEDAHOHIChNOHO PRATsIVNYKA. Elektronne naukove fakhove vydannia «VIDKRYTE OSVITNIe E-SEREDOVYShchE SUChASNOHO UNIVERSYTETU»- DESCRIPTION OF DIGITAL COMPETENCE OF A TEACHER. Electronic scientific professional publication «OPEN EDUCATIONAL E-ENVIRONMENT OF THE MODERN UNIVERSITY»1-53. Retrieved from https://doi.org/10.28925/24140325.2019 s39 [in Ukrainian].

13. Nalyvaiko O.O. (2018). Formuvannia informatsiino-tsyfrovoi kompetentnosti yak rezultat profesiinoi pidhotovky studentiv klasychnykh universytetiv [Formation of information and digital competence as a result of professional training of students of classical universities]. Pedahohichnyi almanakh - Pedagogical almanac, 40. [in Ukrainian]. 
14. Trykhonova O.M.

(2018)

Informatsiino-tsyfrova kompetentnist: zarubizhnyi ta vitchyznianyi dosvid [Information and digital competence: foreign and domestic experience]. Naukovi zapysky. Seriia: Pedahohichni nauky - Research Papers. Series: Pedagogical sciences, 173, 221-225[in Ukrainian].

15. Ferrari, A. Digital Competence in Practice: An Analysis of Frameworks. Luxemburg: IPTS-JRC. 2011.

\section{Вступ}

У статті актуалізується проблема формування цифрової компетентності майбутніх педагогів професійного навчання (сфера обслуговування) у процесі професійної підготовки за допомогою забезпечення нового ресурсного потенціалу в умовах «цифровізації» суспільства. Ефективна освіта повинна мати випереджувальний характер спираючись на вимоги економіки і соціальної сфери країни. При цьому, в контексті розвитку сучасної педагогічної науки, саме цифрова компетентність педагога повинна стати основою підготовки конкурентоспроможних фахівців нової формації, які відповідатимуть ключовим науковим і практичним завданням суспільства та будуть готовими до викликів майбутнього.

Звертаючись до дослідження Морзе Н., варто сказати, що цифрова компетентність педагогічного працівника $-\epsilon$ багаторівневою професійно-особистісною характеристикою в сфері цифрових технологій його складне динамічне цілісне інтегративне утворення особистості, що обумовлене 3 одного боку потребами та вимогами цифрового суспільства, а 3 іншого появою освітнього простору, який змінює навчально-виховну взаємодію всіх іiі учасників, характеризується широким залученням до використання мережі Інтернет, цифрових систем зберігання та первинної обробки та систематизації даних, а також автоматизованих цифрових аналітичних систем (на основі нейромереж та штучного інтелекту), що дозволяє насамперед ефективніше здійснювати професійну діяльність та водночас стимулює до постійного професійного саморозвитку (Morze N., Bazeliuk O., Vorotnikova I., Dementiievska N., Zakhar O., Nanaieva T., Pasichnyk O., \& Chernikova L. 2019).

На сьогоднішній день освіта перебуває на такому етапі розвитку, коли «цифровізація» торкається усіх його проявів, та вимагає ради- 
кальних змін, які повинні відбуватися у системі професійної освіти зокрема. Адже, тільки компетентний педагог може забезпечити рівний та неперервний доступ усіх до цифрової освіти, а це є ключовою основою до структури формування цифрової компетентності майбутніх педагогів професійного навчання (сфери обслуговування) у процесі професійної підготовки (Генсерук\&Мартинюк, 2019:159).

Звертаючись у своєму дослідженні до концепції розвитку цифрової економіки та суспільства України на 2018-2020 роки, зазначалося, що «основною метою цифровізації є досягнення цифрової трансформації існуючих та створенні нових галузей економіки, а також трансформації сфер життєдіяльності у нові більш ефективні та сучасні. Варто наголосити на тому, що цифровізація - це насичення фізичного світу електронно-цифровими пристроями, засобами, системами та налагодження електронно-комунікаційного обміну між ними, що фактично уможливлює інтегральну взаємодію віртуального та фізичного, тобто створює кіберфізичний простір. Такий приріст є можливим лише тоді коли ідеї, дії, ініціативи та програми, які стосуються цифровізації, будуть інтегровані, зокрема, в національні, регіональні, галузеві стратегії і програми розвитку» (Kontseptsiia rozvytku tsyfrovoi..., 2018).

Сучасне інформаційне суспільство характеризується становленням та розвитком техногенно-інформаційного суспільства 3 використанням інформаційно-комунікаційних технологій. При цьому способи отримання та передачі інформації все частіше носять в собі цифровий характер, адже освіта має працювати на випередження, та в майбутньому забезпечувати сталий характер інноваційного розвитку (Трихонова, 2018:221).

«В сучасних умовах розбудова національної системи освіти 3 урахуванням усіх історичних та інноваційних викликів XXI ст. вимагає критичного осмислення досягнутого та зосередження зусиль на найбільш гострих питаннях та проблемах, що стримують сучасний розвиток не дають можливості забезпечити нову якість освіти, адекватну нинішній історичній епосі» (Трихонова, 2018:221).

Серед зазначених проблем особливо актуальною є формування цифрової компетентності майбутніх педагогів загалом та педагогів професійного навчання (сфера обслуговування) зокрема відповідно до потреб інформаційного суспільства, що обумовлено 
недостатньою увагою до даної проблеми з боку наукової спільноти та держави. Вважаємо, що цифрова компетентність є основою забезпечення якісної підготовки кваліфікованих фахівців, створення та поширення знань, формування інтелектуального капіталу суспільства, готового до викликів майбутнього. У зв'язку з цим постала потреба обгрунтування сутності та важливості формування цифрової компетентності майбутніх педагогів професійного навчання (сфера обслуговування) у процесі професійної підготовки.

\section{Матеріал і методи досліджень}

У процесі підготовки статті використовувалася низка загальнонаукових методів дослідження, зокрема - аналіз, синтез, узагальнення та систематизація наукової літератури.

\section{Результати та їх обговорення}

Кандагура К, у своєму дослідженні наголошує, що «глобалізаційні процеси, які відбуваються в світі, активно інтегруються в освітню сферу. Нові можливості сприяють взаємообміну педагогічними знаннями та практичними навичками, міжкультурними проектами та ідеями. Глобалізація вимагає поєднання національних і світових цінностей в сфері освіти, зміни напрямків і принципів освіти» (Кандагура, 2018). Одним із головних пріоритетів сучасного демократичного суспільства $є$ розвиток якісної освіти, за допомогою якої формується всебічно-розвинена особистість та відповідальний громадянин своєї держави (Наливайко, 2018). Одним із основних напрямків реформування навчальних закладів є інформатизація освіти, яка включає індивідуальний розвиток особистості (Genseryk, 2019). Процес професійного навчання майбутніх педагогів має бути спрямований не лише на становлення базових компетентностей для подальшої фахової діяльності, але й для формування творчого потенціалу, вдосконалення та розвитку подальшої кар'єри (Галузяк, 2016).

Методи і технології, які використовуються в освітніх процесах та передбачають їх комплексну модернізацію - це концепція Smart education(«Shcho take SmartEducation?», 2017). На нашу думку професійна компетентність, поєднує в собі знання, уміння, досвід, професіоналізм, що в інтеграції цих понять дозволяє фахівцеві використовувати теоретичну та практичну діяльність у своїй праці, компетенція тут розуміється як сфера повноважень, в 
якому фахівець реалізовує свою професійну компетентність (Галузяк, 2016).

У своєму дослідженні звертаючись до словника сучасної англійської мови Лонгмена, для того щоб розмежувати два поняття «компетентність» та «компетенція», варто вказати на те, що «компетенція відноситься до кола питань що стосуються суб'єкта діяльності. Компетентність - це здобуток особистості, тобто те, завдяки чому людина може вирішувати професійні завдання» (Longman Dictionary of..., 2007). Ми вважаємо виправданим поділяти позицію авторів, що схиляються до думки, що компетенція - це коло повноважень фахівця, компетентність - це визначення здатності особистості до ефективного виконання певних професійних завдань (Галузяк, 2016: 65).

Зокрема, у сучасному словнику англійської мови Longman Dictionary of Contemporary English ці поняття також не розмежовуються, компетенція та компетентність визначається, як вміння робити щось вдало (Longman Dictionary of..., 2007:291).

Зарубіжний науковець Феррарі А. у своєму дослідженні розуміє поняття цифрової компетентності, як здатність кваліфіковано здійснювати педагогічну діяльність, орієнтуватися в інформаційному просторі та оперувати даними відповідно до власних потреб, та сучасного інформатизованого суспільства (Феррарi, 2011).

Биков В.Ю у власному дослідженні зазначає, що цифрова компетентність майбутнього педагога, повинна бути неупередженною із критичним поясненням інформаційних даних, які у свою чергу мають застосовуватися для створення, обміну, пошуку інформації (Биков, 2016).

Крістін Редекер та Ів Пуні у своєму дослідженні трактують «цифрову компетентність як впевнене, критичне і відповідальне використання та взаємодію інформації з цифровими технологіями для навчання, професійної діяльності (роботи) та участі у житті суспільства» (Christine Redecker\&Yves Punie, 2017).

У Концепції нової української школи зазначається, що «велике значення має інформаційна й медіа-грамотність, основи програмування, алгоритмічне мислення, робота з базами даних, здобуття навичок безпеки в Інтернеті та кібербезпеці, розуміння 
етики роботи з інформацією (авторське право, інтелектуальна власність тощо)» (Kontseptsiia novoi ukrainskoi..., 2016).

У 2016 p. Кабінетом Міністрів України в умовах інформатизації освіти в Україні, та з метою інтеграції у світові процеси було презентовано проект «Цифровий порядок денний України 2020» («Digital Agenda for Ukraine 2020»). Концепція та План дій розвитку цифрової економіки в Україні до 2020 року, яка була схвалена на засіданні Уряду, та $є$ продовженням такої інтеграції, що сприяє інформатизації освітнього процесу (Генсерук, 2019).

Дедалі частіше для інтеграції із європейським освітнімпростором в Україні поширюється поняття «цифрової компетентності», як вміння використовувати інформаційно-цифрові технології у педагогічній та освітній діяльності.

Морзе Н., у своєму дослідження наголошує, що цифрова компетентність педагогічного працівника має забезпечувати ефективний розвиток усіх його складових: критичне оцінювання інформаційних даних, медіаграмотність, повага до авторського права, вміння використовувати цифрові дані у навчальній та життєвій ситуаціях, розуміння понять хмарних технологій, кодування елементів штучного інтелекту, вирішення професійних проблем за допомогою цифрових технологій (Morze N., Bazeliuk O., Vorotnikova I., Dementiievska N., Zakhar O., Nanaieva T., Pasichnyk O., \& Chernikova L. 2019).

Як зазначається у концепції розвитку цифрової економіки та суспільства України на 2018-2020 роки, основними напрямами цифровізації освіти є:

- «3 підтримкою інтерактивного та мультимедійного контенту для загального доступу закладів освіти та студентів, зокрема інструментів автоматизації головних процесів роботи навчальних закладів створюються спеціальні цифрові платформи;

- для створення цифрового навчального середовища (мультимедійні класи, науково-дослідних STEM-центрів лабораторії, інклюзивні класи, класи змішаного навчання), розробляються та впроваджуються інноваційні комп'ютерні, мультимедійні та комп'ютерно-орієнтовані засоби навчання та обладнання; 
- організація широкосмугового доступу до Інтернету студентів у навчальних аудиторіях в закладах освіти на всіх рівнях;

- 3 використанням когнітивних та мультимедійних технологій створюється розвиток дистанційної форми освіти» (електронне посилання).

Застарілі методики використання інформації у педагогічній діяльності призводять до нерозуміння понять студентами та неможливість їх візуалізувати на практиці. На нашу думку, педагогічні працівники мають критично відноситися до інформації, бути медіаграмотними та іти в «ногу з часом».

Морзе Н., у своєму дослідженні описує цифрову компетентність педагогічного працівника за 5-ма напрямками:

1) Цифрове суспільство. Цифрові технології та сервіси використовуються тут, для участі у суспільній діяльності, вираження власної громадянської позиції, та загалом для розуміння та сприймання цифрових ресурсів у житті людини;

2) Електронне урядування. Цифрові сервіси використовуються для розуміння понять «електронна ідентифікація громадян», «відкритті дані», здійснення студентського документообігу та врядування;

3) Електронна школа. Цифрові технології використовуються для планування та моніторингу освітнього процесу (введення цифрових журналів, тестування студентів, статистичних звітів), активного сприяння подальшому розвитку освітньої політики з використання цифрових технологій в закладах освіти;

4) Електронне навчання суть якого полягає у подальшому розвитку, вдосконаленню навчання, та підвищення кваліфікації, електронного навчання студентів;

5) Безпека в цифровому суспільстві. «Цифрові технології та сервіси використовуються для розпізнавання та протидії маніпуляційних технологій i пропаганди, перевірки надійності джерел і достовірності даних, небезпек в цифровому просторі розуміння важливості відповідальної і безпечної поведінки в цифровому просторі, захисту персональних даних та приватності, запобігання онлайн-злочинів в цифровому суспільстві, розуміння впливу цифрових технологій на навколишнє середовище, 3 точ- 
ки зору їх утилізації» (Morze N., Bazeliuk O., Vorotnikova I., Dementiievska N., Zakhar O., Nanaieva T., Pasichnyk O., \& Chernikova L. 2019:6-7).

На нашу думку формування цифрової компетентності академічної спільноти та здобувачів має бути важливим напрямом розвитку кожного закладу вищої освіти. Актуалізація проблеми цифровізації освіти, активізація використання сучасних цифрових освітніх інструментів спонукатиме педагогів активно розвиватися, професійно зростати та сприятиме формуванню умінь у здобувачів визначати необхідну інформацію, аналізувати складні процеси та знаходити оптимальні рішення для застосування їх у мінливому цифровому середовищі.

Вважаємо, що окрему увагу в межах дисципліни педагогічного спрямування варто присвятити питанням інтеграції цифрових інструментів в освітній процес підготовки майбутніх педагогів професійного навчання (сфера обслуговування). В процесі професійної підготовки, здобувачі мають отримати не лише знання та практичні навички з оптимальної побудови освітнього процесу, але й можливості інтеграції цифрових інструментів в освітній процес, зокрема в сфері реалізації сучасних інноваційних освітніх технологій та методів навчання, як то: перевернуте навчання (flipped learning), змішане навчання (blended learning), метод проектів, метод кейсів, технології активного викладання, BYOD та інші.

Майбутніх педагогів професійного навчання (сфера обслуговування) необхідно ознайомлювати 3 можливостями використання інструментів візуалізації (Canva, Visme, Easel.ly, Venngage, Piktochart), проведення відеоконференцій та вібінарів (MSTeams, Zoom, Free Conference, My Own Conference, Cisco WebEx), poбoти $з$ відео з екрану (CamStudio, Open Broadcaster Software, Jing, Screencast-O-Matic), майндмепінгу (XMind, WiseMapping, Spider Scribe, Mind42, FreeMind, Mindmeister, Mindjet), хмарки слів (Wordclouds, Tagxedo, Tagul), відтворення хронологіï (TimeToast , Timeline JS, Histropedia, Sutori, TimeToast) створення презентацій (Prezi, Emaze, Moovly), онлайн тестування та опитування (Mentimeter, Classtime, Kahoot, Poll Everywhere, ClassMaker), побудови зворотного зв'язку (Padlet, Slack) та інших. 


\section{Висновки}

В умовах реформування освіти, ключова роль належить педагогу, як ініціатору ідей що сприятиме подальшому розвитку наскрізних умінь здобувачів. Інноваційна, якісна та доступна освіта, яка забезпечує успішну реалізацію потенціалу особистості не можлива без формування цифрової компетентності педагога та впровадження цифрових технологій в освітній процес. Цифрова компетентність майбутнього педагога професійного навчання (сфера обслуговування) є одним із визначальних складників компетентності професійної та трактується як одна із ключових якостей та вмінь, ефективно, інформативно та систематично використовувати у своїй діяльності сучасні цифрові освітні інструменти та інформаційно-комунікаційні технології.

Вважаємо, що формування цифрової компетентності майбутніх педагогів професійного навчання (сфера обслуговування) сприятиме не лише підвищенню якості освіти, але і дозволить сформувати фаховий та освітньо-науковий потенціал на засадах безперервного професійного й особистісного розвитку, орієнтований на найкращі досягнення та практики, інтегрований у світовий освітній та дослідницький простір.

\section{Редзюк Н.П., Різник В.В.}

\section{Теоретичні аспекти формування цифрової компетентності майбутніх педагогів професійного навчання (сфера обслугову- вання) у процесі професійної підготовки}

\section{Анотація}

У статті проаналізовано європейські стандарти щодо визначення цифрової компетентності, які є важливим інструментом для підвищення рівня цифрової компетентності фахівців у галузі освіти. Для визначення поняття цифрової компетентності вивчено різні підходи та термінологію, яка використовується у сучасній науковопедагогічній літературі. Смисловий контент поняття «цифрової компетентності» $є$ провідною ознакою цифрової грамотності, та характеризує навички роботи в інформаційно-комунікаційному середовищі, та його соціокультурну складову (відповідні ціннісні 
орієнтири та особистісний досвід). На ефективність цифровізації освіти позитивно впливає інформатизація системи освіти, що сприяє формуванню інформаційної компетентності майбутніх педагогів. Одним із визначальних складників професійної компетентності є цифрова компетентність педагога професійного навчання (сфера обслуговування), що трактується як одна із ключових якостей та вмінь, ефективно, інформативно та систематично використовувати у своїй діяльності сучасні цифрові інструменти та інформаційно-комунікаційні технології, вказує на мобільність, сучасність та конкурентноздатність. Нині зростає попит на фахівців у сфері освіти із нестандартним мислення та умінням просувати сучасний контент у освітологію. Основну увагу у статті акцентовано на перспективності розвитку зазначеної компетентності у майбутніх фахівців спеціальності «Професійна освіта (Сфера обслуговування)». Авторами висвітлено сутність та розкрито важливість формування цифрової компетентності майбутніх педагогів професійного навчання (сфера обслуговування) у процесі професійної підготовки, можливості інтеграції цифрових інструментів в освітній процес, зокрема в сфері реалізації сучасних інноваційних освітніх технологій та методів навчання.

Ключові слова: освітнійпроцес, цифровізація, інформатизація, цифрова компетентність, педагоги професійного навчання (сфера обслуговування), цифрові інструменти в освіті, інформаційнокомунікаційні технології.

\section{Редзюк Н.П., Резник В.В.}

\section{Теоретические аспекты формирования цифровой компетент- ности будущих педагогов профессионального обучения (сфера обслуживания) в процессе профессиональной подготовки}

\section{Аннотация}

В статье проанализированы европейские стандарты определения цифровой компетентности, которые являются важным инструментом для повышения уровня цифровой компетентности специалистов в области образования. Для определения понятия цифровой компетентности изучено различные подходы и терминологию, 
которая используется в современной научно-педагогической литературе. Смысловой контент понятие «цифровой компетентности» является ведущим признаком цифровой грамотности, и характеризует навыки работы в информационно-коммуникационной среде, и его социокультурную составляющую (соответствующие ценностные ориентиры и личностный опыт). На эффективность цифровизации образования положительно влияет информатизация системы образования, способствует формированию информационной компетентности будущих педагогов. Одним из основных составляющих профессиональной компетентности является цифровая компетентность педагога профессионального обучения (сфера обслуживания), что трактуется как одна из ключевых качеств и умений, эффективно, информативно и систематически использовать в своей деятельности современные цифровые инструменты и информационно-коммуникационные технологии, указывает на мобильность, современность и конкурентоспособность. Сейчас растет спрос на специалистов в сфере образования с нестандартным мышления и умением продвигать современный контент в освитологию. Основное внимание в статье акцентировано на перспективности развития данной компетентности у будущих специалистов по специальности «Профессиональное образование (Сфера обслуживания)». Авторами освещены сущность и раскрыто важность формирования цифровой компетентности будущих педагогов профессионального обучения (сфера обслуживания) в процессе профессиональной подготовки, возможности интеграции цифровых инструментов в образовательный процесс, в частности в сфере реализации современных инновационных образовательных технологий и методов обучения.

Ключевые слова: образовательный процесс, цифровизация, информатизация, цифровая компетентность, педагоги профессионального обучения (сфера обслуживания), цифровые инструменты в образовании, информационно-коммуникационные технологии. 